\title{
Faktor Yang Mempengaruhi Penggunaan Kontrasepsi Pada Wanita Usia Subur Di Indonesia (Analisis Data Survei Demografi dan Kesehatan Indonesia Tahun 2017 )
}

Ayu Aminatussyadiah ${ }^{1}$, dan Aris Prastyoningsih ${ }^{2}$

(Ayyukiikarii10@gmail.com, aris.prastryoningsih@gmail.com)

\begin{abstract}
Abstrak
Upaya penurunan AKI serta peningkatan derajat kesehatan ibu merupakan salah satu prioritas utama dalam penanganan bidang kesehatan.pelayanan KB tidak hanya untuk pengendalian penduduk namun dapat berkontribusi dalam meningkatakan kesehatan ibu dan bayi. Sehingga dikatakan bahwa program keluarga berencana merupakan kunci pencapaian sasaran Pembangunan MDGs. Tujuan penelitian ini adalah untuk mengetahui hubungan antara umur, pendidikan dan tempat tinggal dengan penggunaan kontrasepsi pada WUS di Indonesia. Penelitian ini menggunakan pendekatan cross-setional dengan menggunakan teknik total sampling. Jumlah sampel dalam penelitian ini adalah 49.627 WUS di seluruh Indonesia. Hasil penelitian ini menunjukkan variabel yang mempengaruhi penggunaan kontrasepsi pada WUS adalah, tingkat pendidikan $(p=0,023)$, daerah tempat tinggal $(p=0,000)$. Sedangkan faktor yang tidak berhubungan dengan pemilihan kontrasepsi adalah faktor umur $(\mathrm{p}$ value $=0,303)$. Kesimpulan dari penelitian ini adalah, tingkat pendidikan dan daerah tempat tinggal mempengaruhi penggunaan kontrasepsi pada WUS. Karena itu pemerintah melalui Badan Kependudukan dan Keluarga Berencana Nasional (BKKBN) tetap memperhatikan program keluarga berencana dan memastikan setiap masyarakat untuk menerapkan program keluarga berencana, serta mendidik dan mempromosikan program keluarga berencana untuk menyelesaikan permasalahan penduduk.
\end{abstract}

Kata Kunci : umur, pendidikan, tempat tinggal, pemilihan kontrasepsi, wanita usia subur

Factors That Influence Use of Contraception in Fertile Age Women in Indonesia (Data Analysis of Indonesia Demographic and Health Survey 2017)

\section{Abstrack}

Efforts to reduce MMR and improve maternal health are one of the main priorities in the handling of the health sector. Family planning services are not only for population control but can contribute to improving maternal and infant health. So it is said that the family planning program is the key to achieving the MDGs Development goals. The purpose of this study was to determine the relationship between age, education and residence with the use of contraception in WUS in Indonesia. This study uses a cross-sectional approach using total sampling techniques. The number of samples in this study were 49,627 WUS throughout Indonesia. The results of this study indicate the variables that influence the use of contraception in WUS are, education level $(p=$ $0.023)$, area of residence $(p=0,000)$. While the factors that are not related to the choice of contraception are the age factor ( $p$ value $=0.303$ ). The conclusion of this study is that the level of education and the area of residence affects the use of contraception in WUS. Therefore, the government through the National Population and Family Planning Agency (BKKBN) keeps paying attention to the family planning program and ensures every community to implement the 
family planning program, as well as educating and promoting family planning programs to resolve population problems.

Keywords: age, education, residence, contraception selection, women of childbearing age

\section{Pendahuluan}

AKI di Indonesia berdasarkan data SDKI (2007) masih cukup tinggi,yaitu 228 per 100.000 kelahiran hidup. Selanjutnya berdasarkan hasil SDKI(2012) angka AKI terlihat lebih tinggi dari tahun sebelumnya yaitu meningkatsekitar $57 \%$ bila dibandingkan dengan kondisi pada 2007 hingga menunjukanangka 359 per 100.000 kelahiran hidup. Angka tersebut masih jauh dari targetcapaian MDGs kelima pada tahun 2015 yaitu 102 per 100.000 kelahiranhidup.

Upaya penurunan angka kematian ibu juga masuk ke dalam indikator kelima Millenium Development Goals (MDGs) tahun 2015, yaitu peningkatan kesejahteraan ibu dimana indikator utamanya adalah persalinan oleh tenaga kesehatan yang dihubungkan dengan angka kematian ibu.Upaya penurunan AKI serta peningkatan derajat kesehatan ibu tetap merupakan salah satu prioritas utama dalam penanganan bidang kesehatan.Oleh karena itu pelayanan KB dapat dimaksud tidak hanya untuk pengendalian penduduk namun dapat berkontribusi dalam meningkatakan kesehatan ibu dan bayi.Sehingga dikatakan bahwa program keluarga berencana merupakan kunci pencapaian sasaran Pembangunan MDGs (Kemenkes RI, 2012).

Akseptor KB di Indonesia lebih menyukai pemakaian metode kontrasepsi non-MKJP. Berdasarkan data BKKBN tahun 2014 di Indonesia, persentase pemakaian kontrasepsi suntik 52,62\%, pil $26,63 \%$, kondom 5,50\%, IUD $6,92 \%$, implant 6,96\%, MOW 1,28\%, dan MOP 0,09\%. Mayoritas peserta KB baru didominasi oleh peserta KB yang menggunakan Non MKJP, yaitu sebesar 84,74\% dari seluruh peserta KB baru. Sedangkan peserta KB baru yang menggunakan MKJP hanya sebesar 15,25\%. (BKKBN, 2014b).

Tujuan penelitian ini adalah untuk mengetahui hubungan antara umur, pendidikan dan tempat tinggal dengan penggunaan kontrasepsi pada wanita usia subur di Indonesia.

\section{Metode Penelitian}

Penelitian ini menggunakan metode deskriptif kuantitatif dengan rancangan cross sectional terhadap data Survei Demografi dan Kesehatan Indonesia Komponen Kesehatan Reproduksi Remaja tahun 2017. Penelitian cross sectional merupakan penelitian yang mempelajari/mengukur hubungan antara akibat dengan pajanan atau penyebab dalam waktu yang bersamaan pada suatu waktu. Rancangan cross sectional yaitu mempelajari variabel yang termasuk faktor resiko dan variabel yang termasuk efek diobservasi sekaligus pada saat yang sama. Variabel bebas (independen) dalam penelitian ini adalah faktor-faktor yang mempengaruhi penggunaan alat 
kontrasepsi.Sedangkan variabel terikat (dependen) dalam penelitian ini adalah penggunaan alat kontrasepsi.

Populasi pada penelitian iniadalah seluruh wanita usia subur usia 15-49 tahun di seluruh Indonesia yang berjumlah 49.627 orang dan sampek berjumlah 8736 orang. Penelitian ini menggunakan analisis bivariate, melihat adanya hubungan variabel bebas dan variabel terikat (Sugiyono, 2005).

Penelitian ini telah lolos keterangan kelaikan etik (ethical clierence) dari Komisi etik Penelitian Kesehatan Universitas Respati Yogyakarta dengan No. 126.3/FIKES/PL/V/2019.

\section{Hasil}

1. Analisi Univariat

Diagram 1.Distribusi Frekuensi KarakteristikUmur Responden

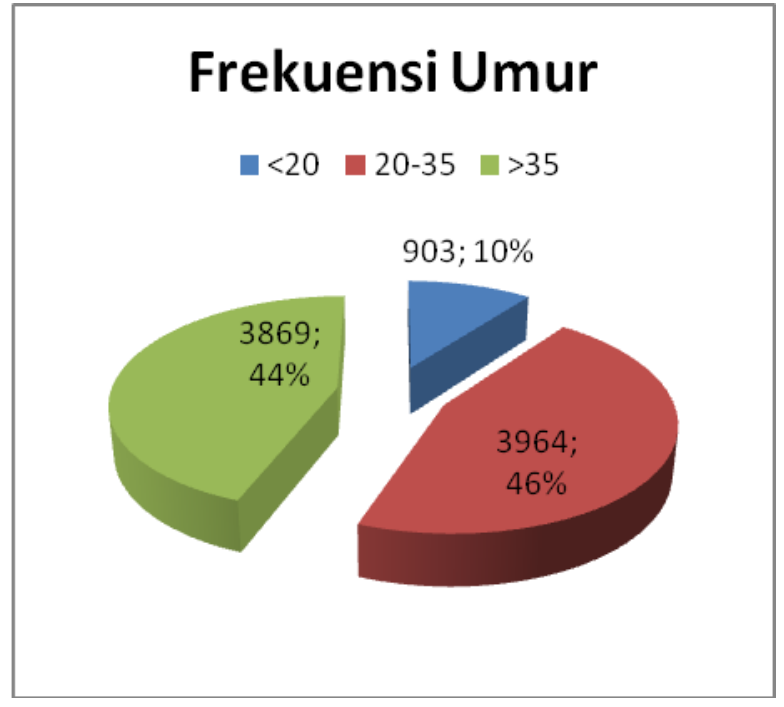

Diagram 2.Distribusi Frekuensi

Karakteristik Tempat Tinggal Responden

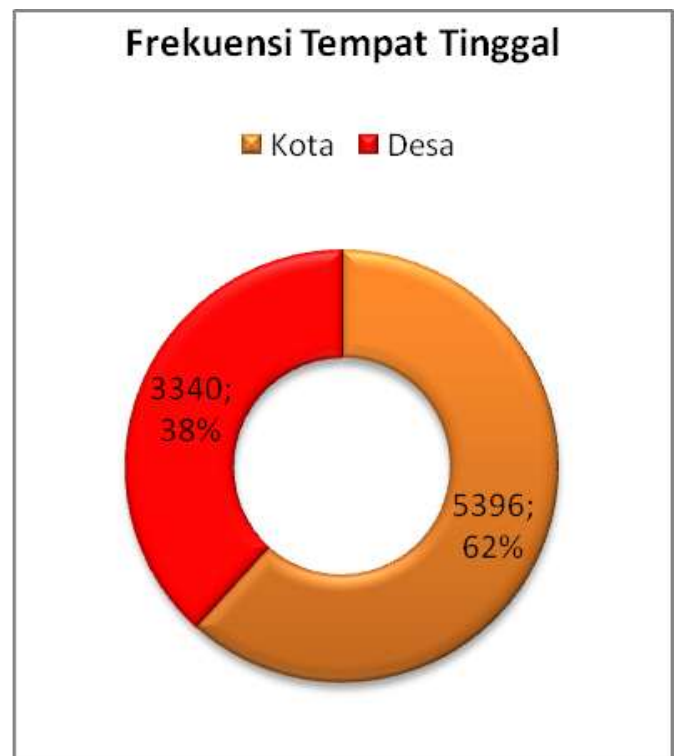

Diagram

3. Distribusi

FrekuensiKarakteristik Pendidikan

Responden

\section{Frekuensi Pendidikan}

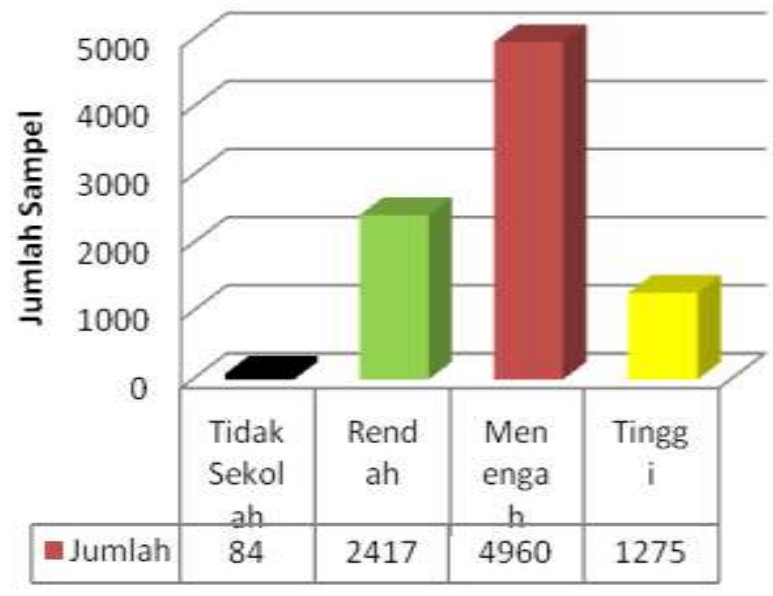

Diagram 4. Distribusi Frekuensi Karakteristik Penggunaan Kontrasepsi Responden 


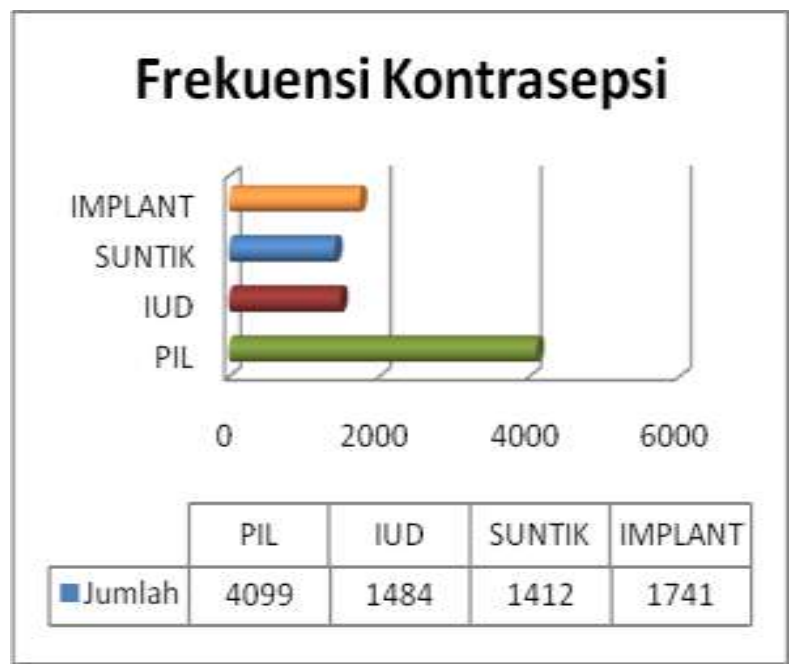

2. Analisis Bivariat

Tabel 1. Hubungan Umur dengan Penggunaan Kontrasepsi Pada Wanita Usia Subur

\begin{tabular}{|c|c|c|c|c|c|c|c|}
\hline & & \multicolumn{4}{|c|}{ Kontrasepsi } & \multirow{2}{*}{ Total } & \multirow{2}{*}{$\begin{array}{c}\text { P- } \\
\text { value }\end{array}$} \\
\hline & & Pil & Iud & Suntik & Implant & & \\
\hline \multirow{3}{*}{ Umur } & $<20$ & 441 & 152 & 129 & 181 & 903 & \multirow{4}{*}{0,303} \\
\hline & $\begin{array}{l}20- \\
35\end{array}$ & 1846 & 657 & 638 & 823 & 3964 & \\
\hline & $>35$ & 1812 & 675 & 645 & 737 & 3869 & \\
\hline Total & & 4099 & 1484 & 1412 & 1741 & 8736 & \\
\hline
\end{tabular}

Berdasarkan Tabel 1, diketahui bahwa penggunaan alat kontrasepsi pada wanita usia subur sebagian besar adalah wanita berusia 20-35 tahun dengan penggunaan alat kontrasepsi Pil, sedangkan penggunaan kontrasepsi paling sedikit yaitu usia $<20$ tahun dengan pilahan penggunaa kontrasepsi suntik.

Berdasarkan hasil uji statistik diperoleh nilai $p$-value $=0,303$ sehingga dapat diartikan bahwa pada tingkat kemaknaan 5\% tidak terdapathubungan antara umur responden dengan penggunaan kontrasepsipada wanita usia subur di Indonesia.

Table 2. Hubungan Tempat Tinggal dengan Penggunaan Kontrasepsi Pada Wanita Usia Subur

\begin{tabular}{|c|c|c|c|c|c|c|c|}
\hline & & \multicolumn{4}{|c|}{ Kontrasepsi } & \multirow{2}{*}{ Total } & \multirow{2}{*}{$\begin{array}{c}\mathrm{P}- \\
\text { value }\end{array}$} \\
\hline & & Pil & Iud & Suntik & Implant & & \\
\hline Tempa & Kota & 2453 & 2078 & 873 & 992 & 5396 & \\
\hline $\begin{array}{c}\mathrm{t} \\
\text { Tingga } \\
l\end{array}$ & Desa & 1646 & 406 & 539 & 749 & 3340 & 0,000 \\
\hline
\end{tabular}

Berdasarkan Diagram diketahui bahwa dari 20-35 tahun sebanyak 3964 (46\%), dan pendidikan tertinggi yaitu pendidikan menengah (SMA) sebanyak 4960 (57\%), danlebih banyak bertempat tinggal di kotayaitu berjumlah $5396 \quad(62 \%)$, serta penggunaan kontrasepsi yang banyak di pilih adalah kontrasepsi Pil berjumlah 4099 (47\%). 


\begin{tabular}{llllll} 
Total & 4099 & 1484 & 1412 & 1741 & 8736 \\
\hline
\end{tabular}

Berdasarkan Tabel 2, diketahui bahwa penggunaan alat kontrasepsi pada wanita usia subur sebagian besar bertempat tinggal di kota dengan penggunaan alat kontrasepsi terbanyak adalah menggunakan kontrasepsi Pil, sedangkan penggunaan kontrasepsi di desa paling sedikit memilih menggunakan kontrasepsi IUD.

Berdasarkan hasil uji statistik diperoleh nilai $p$-value $=0,000$ sehingga dapat diartikan bahwa pada tingkat kemaknaan 5\% terdapat hubungan yang signifikan antara tempat tinggal responden dengan penggunaan kontrasepsipada wanita usia subur di Indonesia.

Tabel 3. HubunganPendidikan dengan Penggunaan Kontrasepsi Pada Wanita Usia Subur

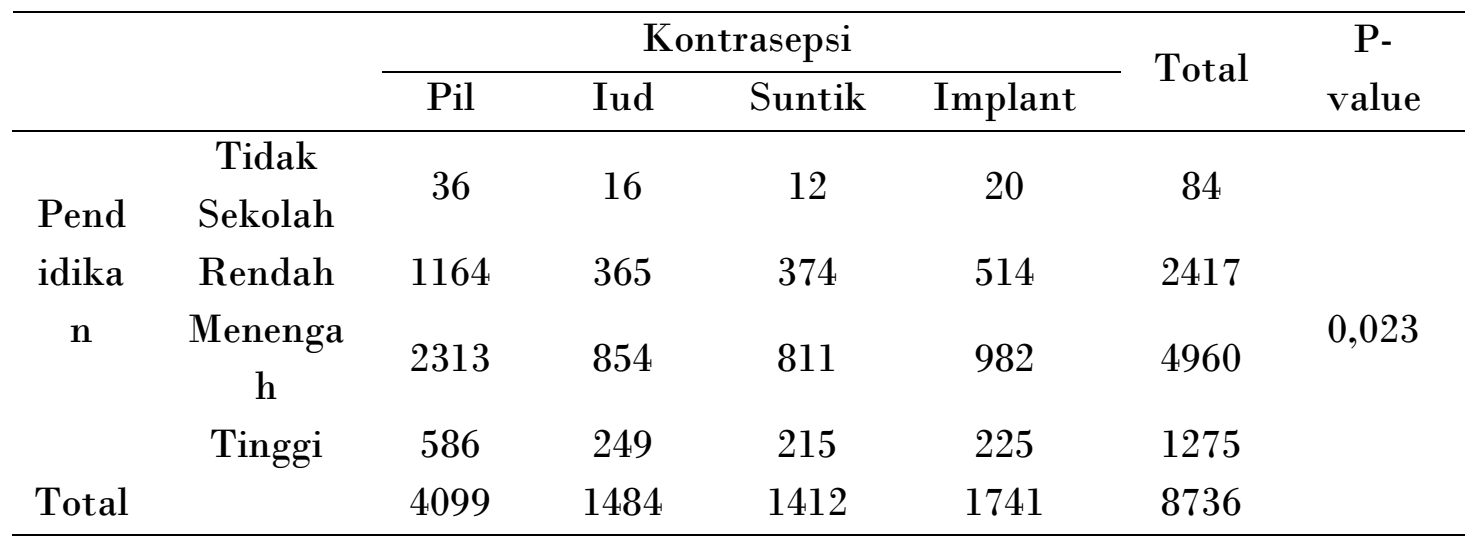

Berdasarkan Tabel 3, diketahui bahwa penggunaan alat kontrasepsi pada wanita usia subur sebagian besar berpendidikan menengah (SMA) dengan penggunaan alat kontrasepsi terbanyak adalah menggunakan kontrasepsi Pil, sedangkan penggunaan kontrasepsi paling sedikit yaitu tidak sekolah dan lebih banyak memilih menggunakan kontrasepsiSuntik.

Berdasarkan hasil uji statistik diperoleh nilai $p$-value $=0,000$ sehingga dapat diartikan bahwa pada tingkat kemaknaan 5\% terdapat hubungan yang signifikan antara tempat tinggal responden dengan penggunaan kontrasepsipada wanita usia subur di Indonesia. 


\section{Pembahasan}

1. Hubungan antara umur dengan penggunaan kontrasepsi pada wanita usia subur di Indonesia

Hasil analisis univariabel karakteristik umur wanita usia subur sekitar 46\% (3964) berusia antara 20 35 tahun. Umur merupakan hal yang sangat berperan dalam penentuan untuk menggunakan alat kontrasepsi karena pada fase-fase tertentu dari umur menentukan tingkat reproduksi seseorang. Umur yang terbaik bagi seorang wanita adalah antara 20-30 tahun karena pada masa inilah alatalat reproduksi wanita sudah siap dan cukup matang untuk mengandung dan melahirkan anak. Bila ditinjau pola dasar penggunaan kontrasepsi yang rasional maka masa mencegah kehamilan AKDR/IUD, dan kondom sedangkan pada masa menjarangkan kehamilan (20-30 tahun) dianjurkan untuk menggunakan kontrasepsi dengan urutan AKDR/IUD, pil KB, suntikan, implant/susuk, kondom dan kontap. Pada masa mengakhiri kehamilan (>30 tahun) dianjurkan untuk menggunakan kontrasepsi dengan urutan kontap, AKDR/ IUD, implant, suntik, pil KB, dan kondom. Dengan demikian umur akan menentukan dalam pemilihan jenis kontrasepsi yang digunakan (Notoatmodjo, 2012).

Berdasarkan analisis yang telah dilakukan, hasil yang diperoleh menunjukkan tidak adanya hubungan yang signifikan antara umur dengan penggunaan alat kontrasepsi dimana $p$-value $=0,303$ lebih besar dari $\alpha=$ 0,05 berarti Ho gagal ditolak yang berarti tidak ada pengaruh antara umur dengan penggunaan alat kontrasepsi pada wanita usia subur.

Menurut teori Long dalam Nursalam ada pengaruh antara umur dengan pemilihan kontrasepsi. Kematangan individu dapat dilihat langsung secara objektif dengan periode umur, sehingga berbagai proses pengetahuan, keterampilan, terkait sejalan dengan bertambahnya umur individu. Sedangkan dari hasil penelitian tidak ada hubungan yang bermakna antara umur terhadap pemilihan kontrasepsi (Nursalam, 2010).

Hasil penelitian ini sejalan dengan penelitian yang dilakukan oleh Marbun (2010) dengan judul analisis perubahan metode alat kontrasepsi pada akseptor KB di desa Cempa Kecamatan Hinai tahun 2010. Dalam penelitiannya juga menunjukkan bahwa tidak ada hubungan yang bermakna antara umur terhadap pemilihan kontrasepsi .

Dalam penelitian ini menyatakan bahwa tidak selamanya umur menunjukkan kedewasaan dan matangnya seseorang dalam menyerap pengetahuan. Hasil penelitian ini lebih menunjukkan adanya hubungan lingkungan, dan dukungan keluarga. Seharusnya dalam pemilihan kontrasepsi harus disesuaikan dengan umur reproduksi 
sehingga tidak menyebabkan beresiko pada akseptor.

2. Hubungan antara tempat Tinggal dengan penggunaan kontrasepsi pada wanita usia subur di Indonesia

Hasil analisis univariabel karakteristik tempat tinggal wanita usia subur sekitar $62 \% \quad(5396)$ bertempat tinggal di daerah kota. Berdasarkan analisis yang telah dilakukan, hasil yang diperoleh menunjukkan adanya hubungan yang signifikan antara tempat tinggal dengan penggunaan alat kontrasepsi dimana $p$-value $=0,000$ lebih kecil dari $\alpha=0,05$ berarti Ho ditolak yang berarti ada pengaruh antara tempat tinggal dengan penggunaan alat kontrasepsi pada wanita usia subur.

WUS di indonesia lebih banyak tinggal di perkotaan dan lebih memilih untuk menggunakan metode kontrasepsi pil. Faktor yang mempengaruhi WUS yang tinggal di perkotaan memiliki pendidikan yang lebih tinggi, lebih mudah untuk menjangkau fasilitas pelayanan kesehatan dan akses untuk mendapatkan informasi dari berbagai media lebih mudah didapat. Hal ini sejalan dengan penelitian yang telah dilakukan oleh Magetin (2016) yang menyatakan bahwa daerah tempat tinggal memiliki pengaruh dalam penggunaan kontrasepsi. Menurut Pastuti dan Wilopo (2007), status tempat tinggal antara perkotaan dan pedesaan dengan penggunaan KB menunjukkan bahwa $58,5 \%$ responden yang tinggal di perkotaan ingin membatasi dan mengatur jarak kelahiran.

3. Hubungan antara pendidikan dengan penggunaan kontrasepsi pada wanita usia subur di Indonesia

Hasil analisis univariabel karakteristik pendidikan wanita usia subur berpendidikan menengah (SMA) sebanyak 4960 (57\%). Pendidikan mempengaruhi kerelaan menggunakan KB dan pemilihan suatu metode kontrasepsi. Pendidikan seseorang dapat mendukung atau mempengaruhi tingkat pengetahuan, dan taraf pendidikan yang rendah selalu bergandengan dengan informasi dan pengetahuan yang terbatas. Wanita yang berpendidikan rendah akan sulit menerima informasi dan tidak tahu bagaimana cara dalam menentukan danmemilih kontrasepsi yang sesuai baginya (Brahm, 2007).

Berdasarkan analisis yang telah dilakukan, hasil yang diperoleh menunjukkan adanya hubungan yang signifikan antara pendidikan dengan penggunaan alat kontrasepsi dimana $p$-value $=0,023$ lebih kecil dari $\alpha=$ 0,05 berarti Ho ditolak yang berarti ada pengaruh antara pendidikan dengan penggunaan alat kontrasepsi pada wanita usia subur.

Tingkat pendidikan merupakan faktor yang sangat menentukan pengetahuan dan persepsi seseorang terhadap sesuatu hal, termasuk keikutsertaan dalam KB. Ini disebabkan seseorang yang 
berpendidikan tinggi akan lebih luas pandangannya dan lebih mudah menerima ide dan tata cara kehidupan baru (Ma'ruf, 2013).

Penelitian ini sejalan dengan Penelitian yang dilakukan oleh Nurbaiti (2013), menggambarkan bahwa pemakaian metode kontrasepsi dipengaruhi oleh tingkat pendidikan sebelumnya dengan praktek pemakaian kontrasepsi. Tingkat pendidikan ini mempempengaruhi keputusan WUS dalam memilih metode kontrasepsi.

\section{Simpulan}

Berdasarkan hasil penelitian dan pembahasan dapat di ambil kesimpulan mengenai faktor yang mempengaruhi penggunaan kontrasepsi pada wanita usia subur di indonesia adalah sebagai berikut : Ada hubungan yang signifikan antara pendidikan dengan pemilihan kontrasepsi pada wanita usia subur di indonesia, ada hubungan yang signifikan antara tempat tinggal dengan pemilihan kontrasepsi pada wanita usia subur di indonesia, tidak ada hubungan yang signifikan antara umur dengan pemilihan kontrasepsi pada wanita usia subur di Indonesia.

Berdasarkan hasil penelitian dan pembahasan, saran-saran yang ditujukan sebagai berikut : meningkatkan Promosi Kesehatan dan motivasi kesehatan melalui KIE (Komunikasi, Informasi, dan Edukasi) mengenai Keluarga Berencana dan alat-alat kontrasepsi sebagai upaya meningkatkan pengetahuan masyarakat mengenai KB dan alat kontrasepsi itu sendiri sehingga dapat membuka wawasan mereka dan menghilangkan isu-isu negatif yang berkembang di masyarakat tentang Metode Kontrasepsi Jangka Panjang ( MKJP) seperti Implant, IUD, dan sterilisasi, mengirim koordinator setiap kecamatan sebagai penggerak penyuluhan KB.

\section{Daftar Pustaka}

Asih, Leli dan Hadriah Oesman. 2009. Faktor yang Mempengaruhi Pemakaian Kontrasepsi Jangka Panjang (MKJP). Jakarta: BKKBN.

BKKBN, 2014b. Pemantauan Pasangan Usia Subur Melalui Mini Survey 2013. Jakarta: Puslitbang, BKKBN

Kemenkes RI. (2012). Buku Seri Etnografi Kesehatan Ibu dan Anak 2012: Etnik Alifuru Seram Desa Waru Kecamatan Bula Kabupaten Seram Bagian Timur Provinsi Maluku. Kemenkes RI

Kusumaningrum, R., 2009. Faktor-faktor yang mempengaruhi Pemilihan jenis kontrasepsi yang digunakan pada pasangan usia subur. Semarang: Fakultas Kedokteran Universitas Diponegoro

Ma'ruf, Nurul. Study Faktor-Faktor yang Mempengaruhi Keefektifan Kontrasepsi Hormonal Di Puskesmas Rappang Kec. Pancarijang Kab. Sidrap. 
Makassar: UIN Alauddin Makassar. 2013.

Magetin, D. M. C., 2016. Analisis Penggunaan Metode Kontrasepsi Oleh Pasangan Usia Subur di Provinsi Jawa Timur dengan Pemodelan Regresi Logistik Multinomial. Universitas Airlangga Manuaba, I.B.G., 2010. Kebidanan, Riwayat Kandungan \& Keluarga Berencana Untuk Pendidikan Bidan. Jakarta: EGC.

Marbun, E, (2010). Analisis perubahan metode alat kontrasepsi pada akseptor KB di desa Cempa Kecamatan Hinai, (http://digilib.unimus.ac.id/files/dis k1/148/5344- 3.pdf, diakses 29 Juni 2011).

Notoadmodjo, S. 2003. Ilmu Kesehatan Masyarakat. Jakarta: Bina Pustaka Sarwono Prawihardjo.

Notoatmodjo, S. Pendidikan dan Perilaku Kesehatan. Rineka Cipta: Jakarta; 2012

Nursalam (2010). Proses dan dokumentasi keperawatan, konsep dan praktek, Jakarta: Salemba Medika.
Putriningrum, R. Faktor-Faktor yang Mempengaruhi Ibu dalam Pemilihan Kontrasepsi KB Suntik di BSP Ruvina Surakarta. Surakarta: Stikes Kusuma Husada; 2010 .

Wilopo, S. A. 2007. Dari Konsep ke Persepsi Wanita terhadap Kualitas Pelayanan Kontrasepsi, Studi Kasus di Yogyakarta. Pusat Penelitian Pranata Pembangunan, Universitas Indonesia.

Brahm, (2007). Ragam metode kontrasepsi, Jakarta : EGC.

Nurbaiti. 2013. Faktor yang Mempengaruhi Penggunaan Alat Kontrasepsi Intra Uterine Device (IUD) di Wilayah Kerja Puskesmas Simpang Tiga Kabupaten Pidie tahun 2003. Jurnal Kebidanan. Diakses pada simtakp.stmikubudiyah.ac.id 